\title{
Effect of storage container on the bacteriological quality of water from different sources
}

\begin{abstract}
This research work was carried out to measure the effect of storage container on the bacterial population of water from different sources over a long storage time. Spread plate and other bacteriological techniques were adopted using Nutrient (NA), Salmonella/ Shigella(SSA), MacConkey(MAC), and Thiosulphite citrate bile sucrose (TCBS) agar. Calabash, Glass, Metal and Plastic containers were used to store rain, river, and tap water samples. Sample analysis was taken at time interval of week $0,1,3,5$, and 14 . In rainwater stored in calabash, total heterotrophic bioload decreased from $9.2 \mathrm{logcfu} / \mathrm{ml}$ at week 0 to $5.3 \log \mathrm{cfu} / \mathrm{ml}$ at week 5 and steady thereafter. Other bioloads in rain water stored in other containers showed similar trend in growth pattern. For river water stored in calabash container, total heterotrophic bioload decreased all through. For river water stored in glass container, it also decreased from $7.0 \operatorname{logcfu} / \mathrm{ml}$ at week 0 to $5.8 \log \mathrm{cfu} / \mathrm{ml}$ at week 1 and was steady thereafter. Other bioloads in river water stored in other containers decreased from week 0 to week 14 at various concentrations. In tap water stored in glass and other containers, all decreased throughout. Several other factors were discovered in this research work to be responsible for the bioload population decrease observed. They include toxins produced during stationary phase as secondary metabolites, acids, nutrient depletion, $\mathrm{pH}$ variation, temperature changes. On the statistical analysis (ANOVA), it showed that the containers have significant effect on the bioload of the stored water after 14 weeks storage as plastic recorded the highest bioload change. To this effect people are advised to use plastic container for water storage for a long period. Also people are to filter the water to remove biofilms formed and debris of bacteria that died due to toxins produced. Nutrient depletion and effect of other factors contributed in bacterial population decrease.
\end{abstract}

Volume 9 Issue 2 - 202 I

\author{
Osuji Malachy Ikeokwu \\ Department of Microbiology, Federal University of Technology \\ Owerri, Nigeria
}

Correspondence: Osuji Malachy lkeokwu, Department of Microbiology, Federal University of Technology Owerri, IMO state, Nigeria, Tel +2348034006542, Email Malachyosuji760@gmail.com

Received: April 23, 202I | Published: April 30, 2021

Keywords: bioload, bacteriological, biofilm, metabolite, nutrients, coliform

\section{Introduction}

Water is the most abundant substance on the earth surface and is used as a universal solvent. ${ }^{1}$ It is inexhaustible in its use. In Nigeria, consumable water is obtained from rivers, springs, streams, rainfall, pools, lakes, pipe borne water and borehole. ${ }^{2}$ Following its abundant nature, water is usually taken for granted in most parts of the world. Water has to be potable before it can be regarded fit for human consumption. When the water falls short of this approved standard, it will harbour pathogenic microorganisms. Various water sources are liable to contamination by various microorganisms.

The organisms contained in the water are generally derived from the soil over which the water flows, birds and human activities. Industrial effluence also play major role in the contamination of the water. In order to protect his health and ensures his well-being, man must have an ample supply of water free from pathogenic and harmful substances. It is therefore as a result of this indispensable nature of water that made Nobel Laureate, Szout- Gyorgy to call it the "matrix of life" (Marlin and Carl 1992). The common sources of water available to man include rain, surface and underground water (Beiger et al 1992, and Connell 1996). ${ }^{3}$

Due to the increase in human population and steady growth in industrializations, the available and supply of safe water can no longer be ordinarily considered. Priestly in 1781 was the first to observe that the reaction between hydrogen and oxygen gas yields water vapour (Kay 1996). The role of water cannot be overemphasized. Its function in transportation, power generation, food production, and processing, manufacturing and waste treatment are absolutely basic, since these activities simply cannot take place without water. Water is an essential element for the maintenance of life and most living organisms can survive only for short periods, without water (Tchobanoglous and Schroeder, 1998). In the case of pipe borne, rain and river water, additional sources of contamination could be from the container used in collecting them. According to Okoro, ${ }^{4}$ for the past 15 years, the problem of providing good drinking water for the teeming number of people in the cities and villages of the developing countries has been of great concern to the various government and World Health Organization (WHO). Today, especially in developing countries, the need for safe water is at its peak.

Rainwater is usually collected during rainfall and with the exception of atmospheric contaminants, is the purest water so far available. Surface water consists of water from shallow wells, river, ponds, lakes and wastewater while ground and underground water include deep wells and springs. Surface water contains more microorganisms than either of the two sources, as it is more prone to contamination. Once surface water is improperly handled or constructed as is the case of shallow well which is poorly maintained especially in rural areas, it can be responsible for the outbreak of diseases by most enteropathogenic organisms such as E. coli, Salmonella, Shigella as well as Peudomonas aeruginosa and klebsiella which multiply in water if sufficient nutrient are available (Okpokwasili and Akujobi, 1996; Nnochiri 1990).

Tap water that was identified as the best source of drinking water is now being contaminated through burst pipe, personal hygiene of 
the workers etc (Nnodim 2000). This has led to suffering of some consumers from diseases like intestinal tract diseases, diarrhoea. These diseases, which are indicative of poor water quality call for monitoring of few portable water sources to determine their public health quality. ${ }^{5}$ Public health quality of drinking water is concerned with whether there is health risk implications associated with it (Clarke 2000). If there is risk associated with the water, it has to be re-subjected to further treatment. Chlorination has been the traditional method employed for the treatment of municipal water supplies (Kay 1996). This treatment method is relatively expensive and the free residual chlorine content of the treated water represents a built-in safety factor against pathogens surviving the actual treatment period and causing recontamination. The disadvantage of chlorination is the incidental production of trace amount of organochlorine compound e.g. Trihalomethane (THM).

To regulate the level of water portability, standard have been set. According to Nester et al, ${ }^{6,7}$ the public water systems in the United States of America are regulated under the safe drinking water Act of 1974, amended in 1986 and 1996. This gives the Environmental Protection Agency (EPA) the authority to set the drinking water standards in order to control the level of contaminants in drinking water. These standards are modified in response to new concerns. The U.S Environmental Protection Agency established in 1972 a maximal THM limit in drinking water of $100 \mu \mathrm{g} / \mathrm{l}^{8}$

\section{Aims and objectives of investigation}

1. To assess the effect of different storage containers on the quality of water samples

2. To assess the effect of long storage time on the bacterial load of the water samples

\section{Materials and methods}

\section{Sample collection}

Water samples from three different sources were collected using three different sterile plastic containers 10 -liter capacity, which was sterilized by rinsing thoroughly with hot water first and followed by $95 \%$ ethanol. One container was used for each sample. The sources are (1) Rainwater within Awaka in Owerri North L.G. A. of Imo State. (2) River water from Otamiri River behind Imo Newspapers, Egbu Road, Owerri. (3) Pipe borne water from Prefab Aladinma in Owerri Municipal Council Imo State. Samples were transported to the laboratory within 45 minutes of collection.

\section{Physical analysis}

Portion of the three samples was analysed to check for different parameters (a) Temperature (b) $\mathrm{pH}$ and (c) Conductivity. The $\mathrm{pH}$ of the water sample was taken using the $\mathrm{pH} / \mathrm{Temp}$ meter by Suntex TS2. Dipping the sensitive electrode into the water does this. The meter was switched on and it shows the $\mathrm{pH}$ value of the sample. The same meter was also used for the determination of temperature. For conductivity, meter by Suntex SC-120 was used like that of $\mathrm{pH}$.

\section{Bacteriological analysis}

\section{Bacteriological count}

The water samples were analysed using spread plate and other bacteriological techniques. The following media were used. (1) Nutrient agar by LAB M for the enumeration of total heterotrophic count. (2) Thiosulphite citrate bile sucrose agar by Merk for the enumeration of total Vibrio count. (3) SS agar by Biotech for the enumeration of total Salmonella/Shigella count and (4) MacConkey agar by Oxiod used for the enumeration of total Coliform. For each of the estimations, the water samples were serially diluted in $9 \mathrm{ml}$ of sterile distilled water up to ten dilutions and a $0.1 \mathrm{ml}$ from each tube plated out by spread plate method. These were done at time interval of week $0,1,3,5$ and 14 .

\section{Standard plate count technique}

The technique used is the spread Plate count. It was done as described by Ogbulie et al. ${ }^{5}$ The sterilized distilled water in the test tube was set on test tube rack. The sample container was agitated very well and $1 \mathrm{ml}$ sterile pipette was used to pipette out $1 \mathrm{ml}$ of sample to the $9 \mathrm{ml}$ distilled water in the test tube. This will make the distilled water to rise to $10 \mathrm{ml}$. Another $1 \mathrm{ml}$ was transferred from this $10 \mathrm{ml}$ after shaking to the second tube. This was continued till the 10th dilution.

A $0.1 \mathrm{ml}$ from each test tube was collected and inoculated on the already set media in the Petri dish (plate). The glass spreader was dipped in alcohol and then flamed. It was used to spread the $0.1 \mathrm{ml}$ over the surface of the medium. Finally, the plates were accurately labelled to avoid confusion. Incubation followed after all the inoculations by inverting the plate while placing them inside the incubator. The incubator was set at $37^{\circ} \mathrm{C}$ and allowed to stay for $18-24$ hours. All the glass wares used were washed, dried and sterilized by dry heat in the hot air oven at $160^{\circ} \mathrm{C}$ for 2 hours. Distilled water for serial dilution was sterilized by autoclaving.

\section{Storage of the samples}

The different water samples (Rain, River and Tap) were each stored in separate containers; calabash, glass, metal and plastic previously sterilized using $2.5 \%$ raw $\mathrm{HCl}$ followed by $95 \%$ ethanol. Samples were periodically collected from these containers for analysis. At the end of the week Zero analysis, the samples were stored in the containers.

\section{Isolation, preservation and identification of pure colonies}

\section{Isolation}

The colonies formed on the four media (TCBS, SSA, NA and MAC) were isolated by several sub-culturing onto fresh media until pure colonies are obtained.

\section{Preservation}

Agar slants were prepared and were used in the preservation of the pure isolates. Streaking method as described by Ogbulie et al., ${ }^{5}$ was used to ensure purity of the isolates.

\section{Identification}

Before test was done, the isolates were first sub cultured on nutrient agar. The following tests were done as described by Ogbulie et al. ${ }^{5}$ These include (1) Gram staining test (2) Motility test (3) Catalase test (4) Methyl red test and (5) Oxidase test.

\section{Estimation of changes in bacterial load of different water samples stored in differrent containers}

The changes of bacteriological population of different water samples stored in different containers were estimated using the formulae. 
Change in population ( $\Delta$ in pop)-population at time $(\mathrm{t})$-population at time $(0)$ Percentage change in population $(\% \mathrm{~A}$ in pop $)=$

$\frac{\text { Change in Bioload }}{\text { Population at time }} \times \frac{100}{1}$

\section{Statistical analysis}

Analysis of results to test if the containers have any significant effect on the bacteriological load of the water samples using anova.

\begin{tabular}{lllllll}
\hline Containers & Week $\mathbf{0}$ & Week I & Week 3 & Week 5 & Week I 4 & Row Total \\
\hline Calabash & 4.87 & 4.25 & 3.79 & 3.5 & 3.3 & I9.7I \\
Glass & 4.87 & 4.28 & 3.51 & 3.45 & 3.38 & 19.49 \\
Metal & 4.87 & 4.32 & 3.75 & 3.38 & 3.08 & 19.42 \\
Plastic & 4.87 & 3.44 & 2.97 & 2.53 & 2.22 & 16.03 \\
Column total & 19.48 & 16.29 & 14.02 & 12.86 & 11.98 & Grand total=74.65 \\
\hline
\end{tabular}

Null hypothesis=Containers have significant effect on the bacteriological load as storage time increases.

Alternative hypothesis=containers have no significant effect on the bacteriological load as storage time increases.

\begin{tabular}{|c|c|c|c|c|}
\hline \multicolumn{5}{|c|}{ Correction term $(C T)=\frac{(\text { Grand Total })^{2}}{r t}=\frac{G^{2}}{r t}=\frac{74.65^{2}}{20}=278.63$} \\
\hline \multicolumn{5}{|c|}{$S S_{\text {total }}=\Sigma X^{2}-C T=4.87^{2}+4.25^{2}+\ldots \ldots \ldots+2.25^{2}-C T=290.63=11.39$} \\
\hline \multicolumn{5}{|c|}{$S S_{\text {row }}=\frac{\Sigma x i^{2}}{r}-C T=\frac{19.71^{2}+19.49^{2}+19.42^{2}+16.03^{2}}{5}-C T=280.49-278.63=1.86$} \\
\hline \multicolumn{5}{|c|}{$S S_{\text {column }}=\frac{\Sigma X j^{2}}{t}-C T=\frac{19.48^{2}+16.29^{2}+14.02^{2}+12.86^{2}+11.98^{2}}{4}-C T=287.57-278.63=8.93$} \\
\hline Source & df & $\begin{array}{l}\text { Sum of } \\
\text { squares }\end{array}$ & Mean of squares & F-value \\
\hline \multirow{3}{*}{ Row } & \multirow{2}{*}{$r-1$} & \multirow{3}{*}{$\frac{\Sigma x^{2}}{r}-C T$} & $\mathrm{SS}_{\text {row }}$ & $\mathrm{MS}_{\text {row }}$ \\
\hline & & & Row df & $\mathrm{MS}_{\text {error }}$ \\
\hline & \multirow{2}{*}{$\mathrm{t}-\mathrm{I}$} & & $\mathrm{SS}_{\text {column }}$ & $\mathrm{MS}_{\text {column }}$ \\
\hline Column & & $\frac{\Sigma X^{2}}{t}-C T$ & Column df & $\mathrm{MS}_{\text {error }}$ \\
\hline \multirow{2}{*}{ Error } & \multirow{2}{*}{$(r-1)(t-1)$} & $t$ & $\mathrm{SS}_{\text {error }}$ & \\
\hline & & & Error df & \\
\hline Total & $(r t)-I$ & & & \\
\hline
\end{tabular}

\begin{tabular}{lllll}
\hline Source & $\begin{array}{l}\text { Degree of } \\
\text { freedom }\end{array}$ & $\begin{array}{l}\text { Sum of } \\
\text { squares }\end{array}$ & $\begin{array}{l}\text { Mean of } \\
\text { squares }\end{array}$ & F-value \\
\hline Row & 3 & 1.86 & 0.62 & 1.72 \\
Column & 4 & 8.94 & 2.24 & 6.22 \\
Error & 12 & 4.31 & 0.36 & \\
Total & 19 & 15.11 & & \\
\hline
\end{tabular}

\section{Interpretation of the statistical analysis}

At df 3, F-tabulated at $99.5 \%$ C.I is 3.49 while F-calculated at the 99.5\% C.I is 1.72 . Since F-calculated is less than the F-tabulated, we accept the Null hypothesis that the containers have significant effect on the bacteriological load of the water samples. Also at $\mathrm{df}$ 4,of $99.5 \%$ C.I, F-tabulated is 3.26 while F-calculated is 6.22. Since the F-Calculated is greater than F-tabulated, we reject the alternative hypothesis.

\section{Results}

The result of the physical analysis of the water samples from different sources was shown in table 1 below.

Table I Physical analysis for week 0

\begin{tabular}{|c|c|c|c|}
\hline Parameter & $\begin{array}{l}\text { Rain } \\
\text { water }\end{array}$ & $\begin{array}{l}\text { River } \\
\text { water }\end{array}$ & Tap water \\
\hline $\mathrm{pH}$ & 8.5 & 9 & 7.4 \\
\hline Conductivity $(\mu / \mathrm{cm})$ & 0.01 & 0 & 0 \\
\hline Temperature (OC) & 31 & 30 & 30 \\
\hline Colour & Colourless & Colourless & Colourless Tasteless \\
\hline Taste & Tasteless & Has taste & Odourless \\
\hline Odour & Odourless & Odourless & 0.11 \\
\hline Bromine & 0.12 & 0.1 & NT \\
\hline Potassium & NT & NT & 0.1 \\
\hline Lead & 0.122 & 0.3 & 0.01 \\
\hline Arsenic & 0.3 & 0.23 & $\mathrm{NH}$ \\
\hline Calcium & $\mathrm{NH}$ & $\mathrm{NH}$ & 0.01 \\
\hline Copper & 0.25 & 0.26 & 0.11 \\
\hline Nickel & 0.3 & 0.31 & NT \\
\hline Zinc & NT & NT & 0 \\
\hline Chromium & 0.68 & 0.65 & \\
\hline
\end{tabular}

$\mathrm{NT}=$ not tested by me, $\mathrm{NH}=$ not of health concern. The two tables showed that there are decrease in temperature, $\mathrm{pH}$ and conductivity with time. The temperature decreased from $31 \mathrm{OC}$ to $260 \mathrm{C}$ after 14 weeks incubations. The $\mathrm{pH}$ also reduced from 9.00 to 5 after 14 weeks incubation

\section{Bacteriological analysis of water samples}

The result of the bacteriological load of the water samples from different sources stored in different containers are shown in Figures 4.1-4.12. 


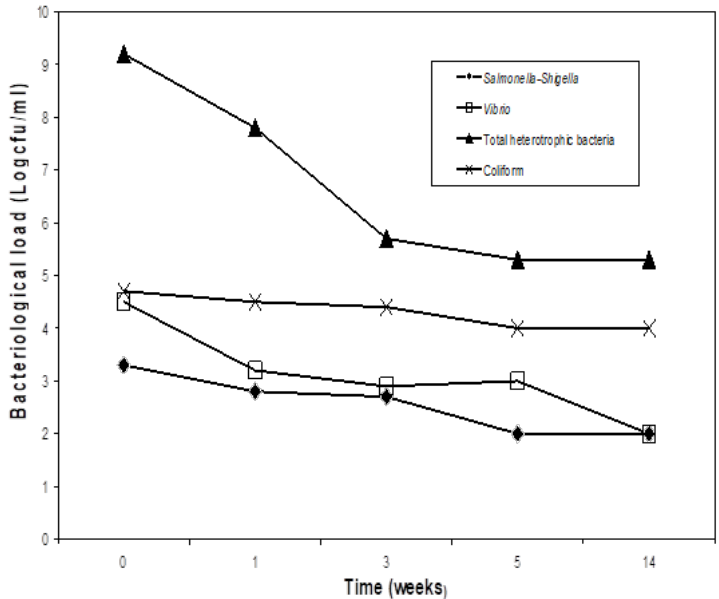

Figure I Bacteriological load of rain water stored in calabash.

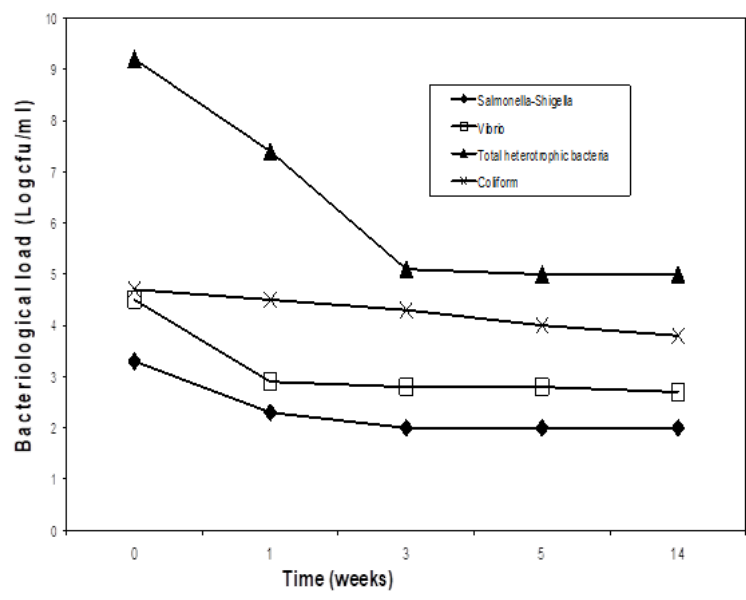

Figure 2 Bacteriological load of rain water stored in bottle.

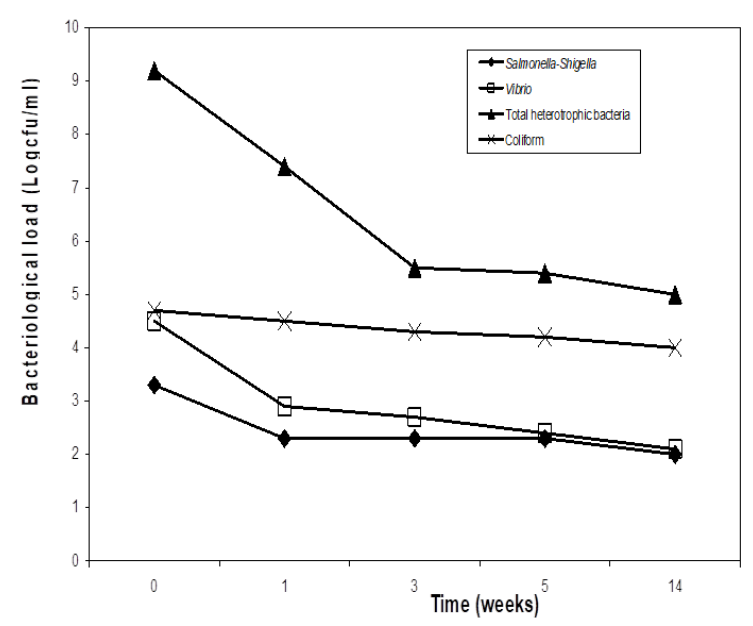

Figure 3 Bacteriological load of rain water stored in metal container.

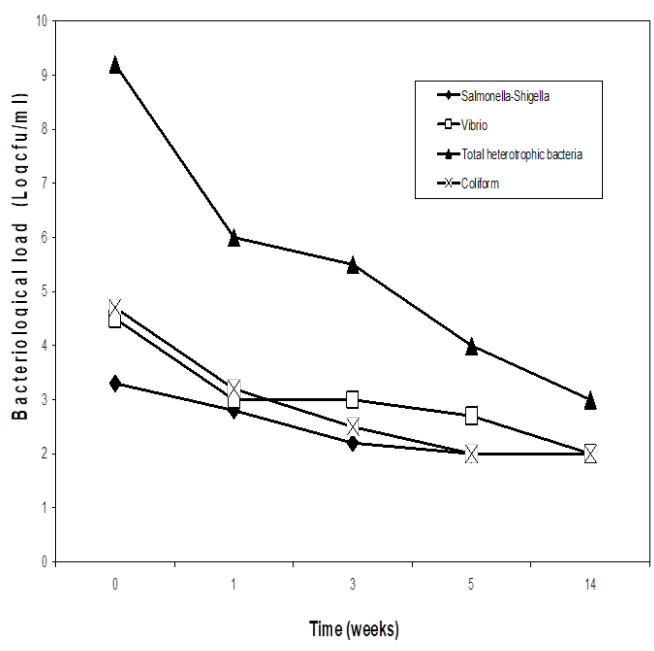

Figure 4 Bacteriological load of rain water stored in plastic.

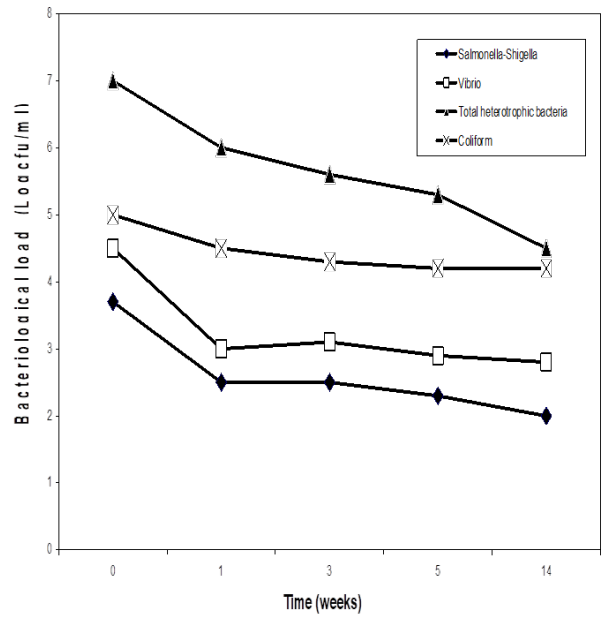

Figure 5 Bacteriological load of river water stored in calabash.

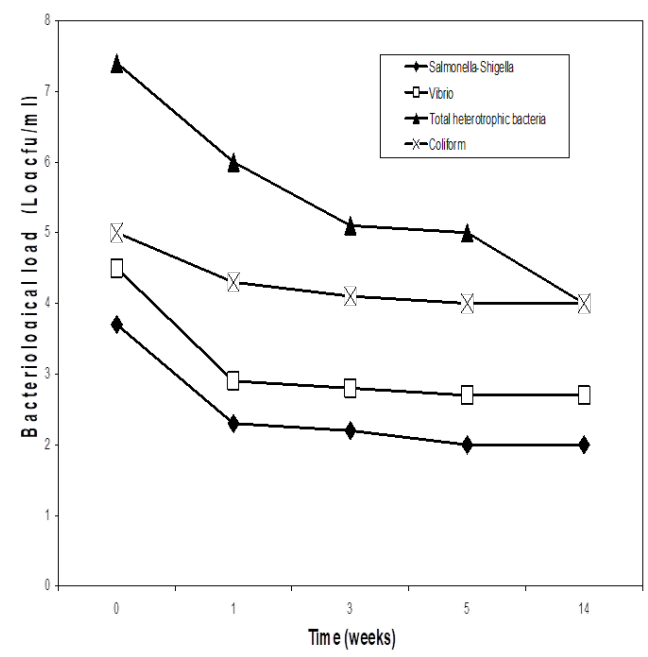

Figure 6 Bacteriological load of river water stored in bottle. 


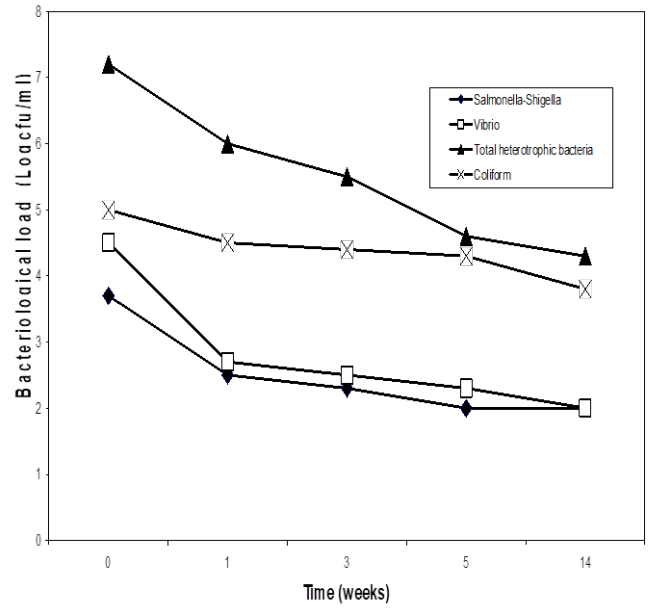

Figure 7 Bacteriological load of river water stored in metal.

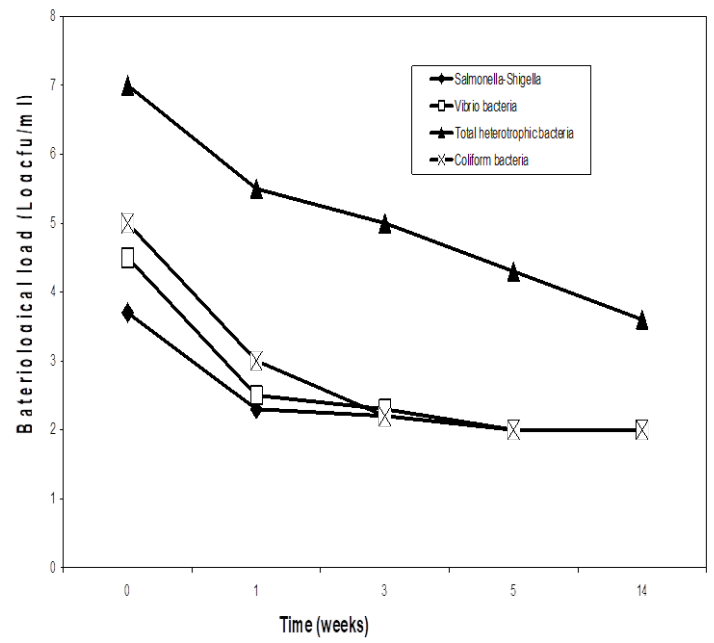

Figure 8 Bacteriological load of river water stored in plastic.

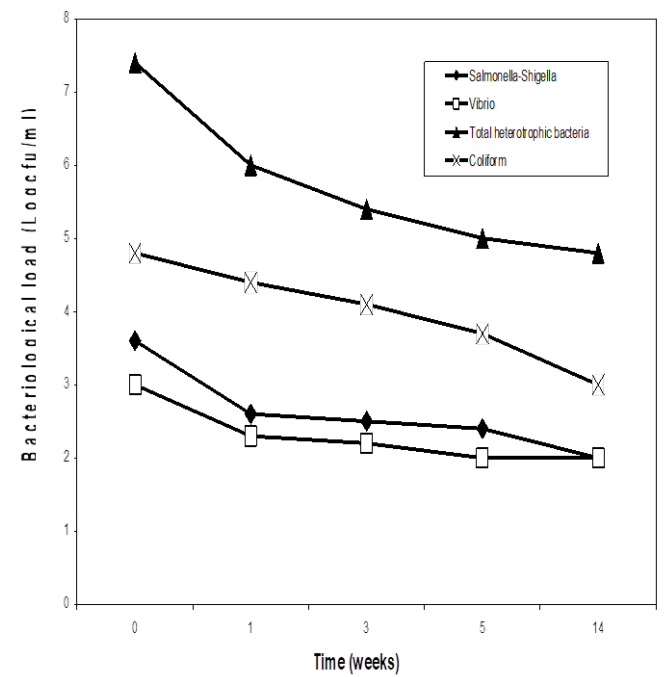

Figure 9 Bacteriological load of tap water stored in calabash.

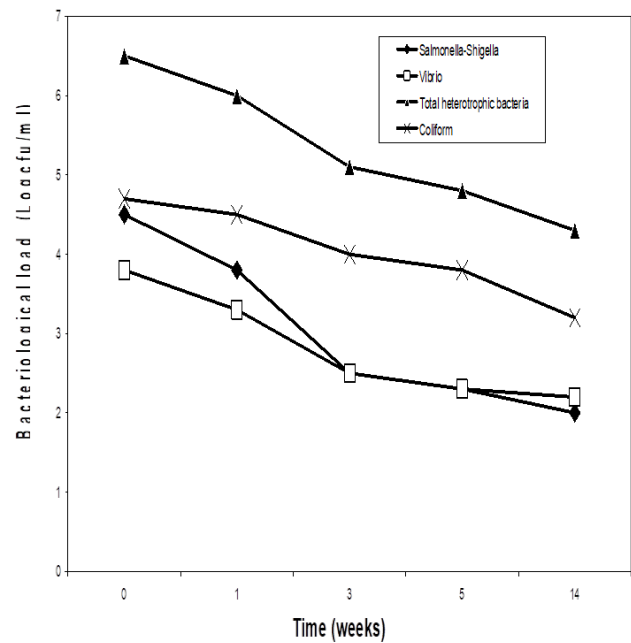

Figure 10 Bacteriological load of tap water stored in bottle.

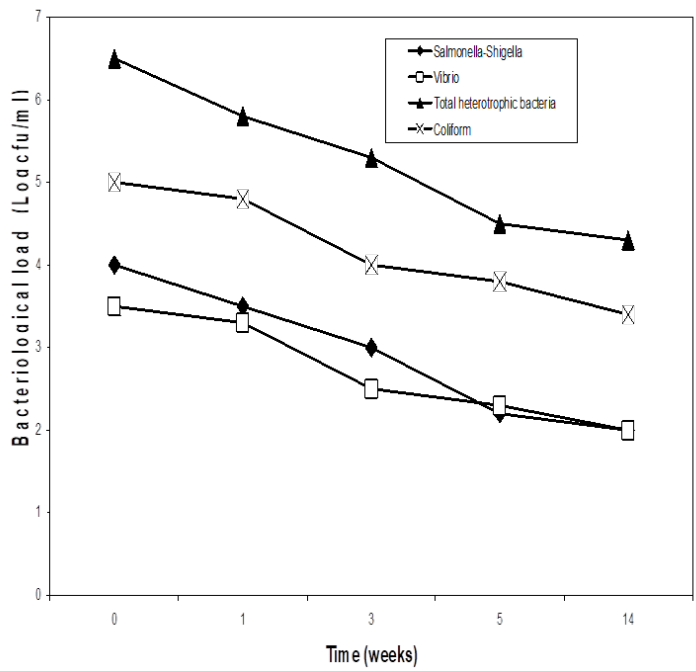

Figure I I Bacteriological load of tap water stored in metal.

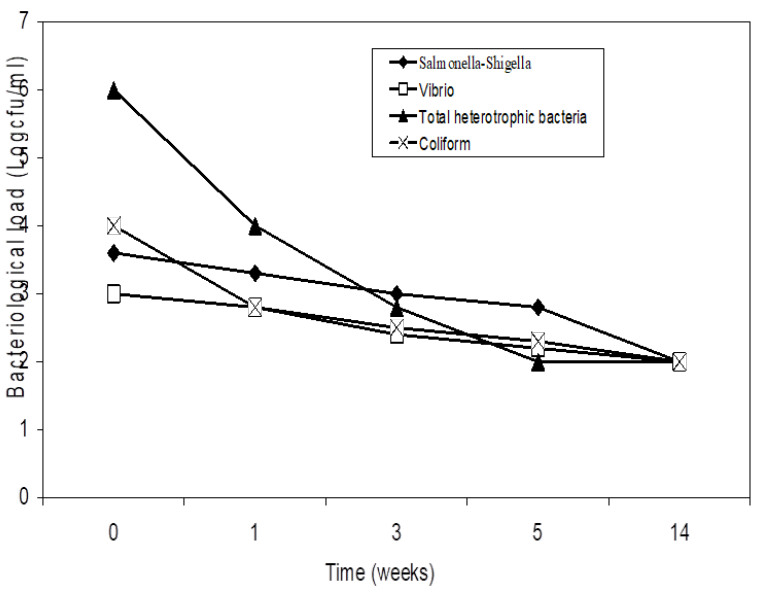

Figure 12 Bacteriological load of tap water stored in plastic. 


\section{Discussion of results}

This research work was done in a batch culture system. All the containers have perfect and tight cork and were never opened to fresh air at any point in time. To this effect, nutrients were not introduced into the stored water sample throughout the incubation periods. At the same time, products were not removed throughout the incubation periods. Under this batch culture system, bacterial load increased in number in a predictable fashion and then eventually declines.

The factors affecting the growth of bacteria in fresh water stored in different containers, usually glass, were studied in order to reconcile the different results which have been obtained by previous workers. Growth occurred in two sites in the body of the water and at the surface of the container and was affected by the constituents of the container. ${ }^{9}$ Bacteria in a flowing water like Otamiri experience continuous culture system. When the water was fetched and stored; the system changes automatically to a batch culture system. According to Taylor \& Collins, ${ }^{9}$ bacteria invariably grew on the sides of the container and were presumably dependent for their multiplication on having a site of attachment; thus the increase in the count per unit volume which occurred when glass were vigorously shaken was greater in small bottles than in large glass, and was due to removal of some of the cells attached to the walls. Soluble chemical substances in the walls of containers retarded bacterial growth. As bacterial load increases at the initial time, available nutrients and level of oxygen begin to deplete.

For water bacteria especially aerobes, the nutrient that becomes limiting is usually oxygen. ${ }^{10}$ They further noted that when the cell concentration exceeds about $1 \times 10^{7} \mathrm{cfu} / \mathrm{ml}$, the growth rate would reduce. Also when the bacterial load reaches $4 \times 10^{9} \mathrm{cfu} / \mathrm{ml}$, the rate of oxygen diffusion will no longer meet the demand. To this effect, there will be reduction in bacterial load. Week 0 of this research work revealed high bacterial load. This could be traced to the abundant nutrient and oxygen in the water sample prior to sample collection.

Apart from the depletion of nutrient and oxygen due to high bacterial load at the start of the storage, other factors are responsible for the low bioload recorded towards the end of the storage period. Berg et al., ${ }^{11}$ and Nester at al (2004) said that as the cell's surroundings change, cells begin to synthesize different enzymes and proteins, which give rise to new metabolites (product of cell's body reaction), e.g. antibiotics and toxins. One astonishing thing that happens at the late $\log$ phase is that it serves as a transition phase to the stationary phase where the secondary metabolites are produced.

It is not possible in this research work to conclude that each week corresponds to a bacterial growth phase. Also it is difficult to give a sharp boundary between phases as regards to the storage time shown in the chart. Nester et al (2004) also noted that as cells die due to the secondary metabolites, they would release their peptide and nucleic acid that will serve as food and energy to those cells that will survive the harsh condition. In this research work, the length of time cells remain in each storage interval varies depending on the species. This has explained why we have different curves in the growth pertain as shown in the chart 4.1-4.12. Apart from the toxins and nutrient depleted condition that led to reduction in bioload, other factors were noticed to have affected the growth of bacterial cells. Pyrex glass and fused silica containers were inactive. It is probable that under the conditions of their experiments some workers have been observing bacteria that were dependent on the glass surface for their existence and which were unable to multiply in the body of the water sample
(Harvey 1992). Glass and plastic recorded a high reduction in bioload of the stored water, but plastic recorded lower bacteriological load than glass. Other factors include the $\mathrm{pH}$ and the temperature. It was noticed that as the $\mathrm{pH}$ enters the acidic region (9.00 at week 0 to 5.00 at week 14), bacterial load reduces. The same was for temperature as it lowers. (31.00 at week 0 to 26.00 at week 14$){ }^{12-36}$

\section{Conclusion}

The batch culture system is a good method of reducing water bacterial load. It is also a typical way of starving the cells. When the cells are confined in this stored condition, they will finish the available oxygen and nutrient. Though there is survival of the fittest, some cells will still remain. This explains why people could store water for so long and microorganism could still be found in the water. The statistical analysis also showed that the container have significant effect on the bioload, because the F-calculated is less than F-tabulated, we accept the Null hypothesis.

\section{Recommendations}

Since run offs into water and broken pipes serves as source of microorganisms to the water; proper refuse disposal, and other sanitary techniques (sanitary landfill) should be devised by government. This could be done through the environment protection agencies to control contamination of natural water. Also governments should not waste time in fixing broken pipes to prevent entrance of pathogens. People should also be educated on the need to use plastic for water storage since it recorded the lowest bacterial load at the end of the storage time. People should also filter their water so as to get rid of the biofilms formed at the wall of the containers and debris of bacteria that died due to toxins, acids and other harmful secondary metabolites produced during the stationary phase of growth as well as nutrient depleted environment.

\section{Acknowledgments}

None.

\section{Conflicts of interest}

Author declares that there is no conflict of interest.

\section{References}

1. Melvin DJ, David OJ, John TN, et al. World of Chemistry. Sanders college publisher: London; 1991. 22 p.

2. Abetianbe SU. The rural dweller and his water source. National Water Bulletin. 1986;1:23-26.

3. Okafor N. Aquatic and waste microbiology. $1^{\text {st }}$ ed. Fourth Dimension publisher: Enugu; 1985. 1-3, 107-126 p.

4. Okoro IJ. Bacteriological Assessment of water From Four villages in Ohaozara L.G.A Imo State. National Journal of Microbiology. 1986;6:12,108-119.

5. Ogbulie JN, Uwaezuoke JC, Ogiehqr SI. Water Quality Microbiology In Introductory Microbiology practical. Springfield publisher: Nigeria; 1998. $114-115 \mathrm{p}$

6. Nester EW, Anderson DG, Robert CE. Bacterial Disease of the Upper Alimentary system: In Microbiology, a Human perspective. $4^{\text {th }}$ ed. McGraw-Hill Comp: New York; 2004. 616-617 p.

7. Nester EW, Anderson DG, Robert CE. Bacterial Growth in Nature and Laboratory Condition in Microbiology, a Human perspective. $4^{\text {th }}$ ed. McGraw-Hill Comp: New York; 2004. 101-104 p. 
8. Mills CJ, Bulls RJ, Cantor K, et al. Health risk of Drinking water chlorination by-Product: Report of an expert working group. Chronic Disease In Canada. 1998;19(3):91-102.

9. Taylor CB, Collins VG. Development of Bacteria in water stored in Glass containers. Freshwater biological association: Way castle, Ambleside Westmorland; 2004.

10. Geo RG, Janet SB, Morse KI. Enteric Gram Negative Rods. In: Medical microbiology. $21^{\text {st }}$ ed. Lange Medical book/Me Graw- hill; 2001. 225$228 \mathrm{p}$.

11. Edberg SC, Allen MJ, Smith DB. National field Evaluation Of a defined substrate method for the simultaneous Enumeration of total Coliform and E.coli from Water: Comparison with the standard multiple tube Fermentation method: Collaborative method. Appl Environ Microbiol. 1988;54(6):15951601.

12. Ballows A. Theprokaryotes. $2^{\text {nd }}$ ed. Springer Verlag: New York, USA; 1992.

13. Blaser MJ, Taylor ND, Feldma AL. Epidemiology of Campylobacterjejun Infection. Epidemiology Review. 1983;5:157-176.

14. CamperAK, Jones WL, Hares JT. Effect Of growth Condition on the presence of coliform in mixed population biofllm. Applied And Environmental Microbiology. 1996;62(11):4018- 4103.

15. Cheesbrough M. Medical laboratory manual for Tropical Countries. Vol II. Microbiology, tropica Health Technology/butterworths \& Co. Ltd: Cambridge; 1984. 34-245 p.

16. Clean water Act, Section 303, 33, U.S.C and 1313.

17. Clean water Act, section 303(d), 33 U.S.C 314 and 1324.

18. Cud D. Total Coliform debate. Australian Water Association, Victoria branch Seminar; 2002

19. Diersing N. Water quality frequently asked Questions. PDA, NOAA; 2009.

20. Fecham RG, Bradley DJ, Gravelick H, et al. Sanitation and disease health aspect Of excreta and wastewater management. Wiley Chi Chester; 1983.

21. Gannon RW, Osmong DL, Humenik FJ, et al. Agricultural Water Quality Water Resources Bulletin. 1996;32(3):437-450.
22. Grabow WO, Botma KL, de Villiers JC, et al. Assessment of cell Culture and Polymerase chain reaction for the detection of Poliovirus in water. Bulletin Of the World Health Organization. 1999;77(12):973-980.

23. Harvey HW. On changes taking place in seawater during storage. Journal of Marine Biology Association of the United Kingdom. 1992;25(2):225.

24. HMSO. Bacteriological Examination of Drinking Water supply 1982. The Microbiology of Water, 1994.

25. Hodgson K, Manus LA. Drinking water Quality framework for South Africa. Water South Africa. 2006;32(5):673-678.

26. International organization for standardization. Water quality; 2008.

27. Johnson DL, Ambrose SH, Basett TJ, et al. Meanings of environmental terms Journal of Environmental quality. 1997;26:581-589.

28. Kock AL. Microbial physiology and ecology of growth. Microbial Molecular Biological Review. 1997;61:305.

29. MacDonnel LJ. Water quality. Land water Law review. 1996;31(2):329348

30. McNeil AR. Microbiological water quality criteria Review for Australia. Australian water resources Council, Technical Paper No 85. Australian Govt Publishing service Canberra; 1985.

31. NZMOH. Drinking water standard for New- Zealand 2000. Ministry of health: New Zealand; 2000.

32. Ogbulie JN, Onyeagba RA, Isu NR. Growth and Reproduction in microbiology In Introductory Microbiology. $1^{\text {st }} \mathrm{ed}$. CRC Publication: Owerri, Nigeria; 1997. $32-44 \mathrm{p}$.

33. Onsdorff KA. Pollution. Environmental law Practice. In: Pelczar MJ, et al., editors. Microbiology.5th edition. Mcgraw-hill; 1996.

34. Philip M. Advanced Chemistry. Cambridge University Press; 1991.558 p.

35. Terry LA. Water pollution. Environmental Law Practice. 2004;4(1):19-26.

36. Tibbets JA. Water Environmental solutions 5(2): 26United state environmental protection agency (EPA) (2006). Washington Dc Water quality Standard review and revision. 1996. 